\title{
Pengaruh Workload, Masa Perikatan Audit dan Spesialisasi Auditor Terhadap Defisiensi Audit pada KAP yang digunakan oleh Perusahaan Manufaktur yang Terdaftar di BEI Tahun 2015-2018
}

\author{
I Gusti Ayu Diah Utari, Ketut Tanti Kustina* dan Putu Gitta Gresia \\ Universitas Pendidikan Nasional Denpasar-Indonesia \\ *tantikustina@undiknas.ac.id
}

How to cite (in APA style):

Utari, I. G. A. D., Kustina, K. T., \& Gresia, P. G. (2021). Pengaruh Workload, Masa Perikatan Audit dan Spesialisasi Auditor Terhadap Defisiensi Audit pada KAP yang digunakan oleh Perusahaan Manufaktur yang Terdaftar di BEI Tahun 2015-2018. Wacana Ekonomi (Jurnal Ekonomi, Bisnis dan Akuntansi). 20 (1), pp.38-48. https:// doi.org/10.22225/we.20.1.3149.38-48

\begin{abstract}
The Effect Of Workload, Audit Tenure, And Auditors' Specialization On Audit Deficiencies Based On Audit Firms Used By Manufacture Companies That Listed On IDX 2015-2018 This study aims to examine whether workload, audit tenure, auditors' specialization influence the occurrence of audit deficiencies conducted by audit firms on the basis of the data that collected by the Finance Finance Professions Supervisory Centre (PPPK), Ministry of Finance RI. This research uses 40 audit firms as population and 34 sample that was collected by purposive sampling method. Workload is measured by the ratio of comparison between total clients and total audit partners. Audit tenure calculated using intervale scale. Auditors' specialization calculated by dummy variable. Basis of the data of audit deficiencies is based on report of audit results by the Finance Finance Professions Supervisory Centre (PPPK), Ministry of Finance RI. This research is quantitative research using multiple linear regression analysis. The results indicate that the workload and audit tenure has a positive impact on audit deficiencies. Auditors' specialization has a negative impact on deficiencies audit.
\end{abstract}

Keywords: Audit; Workload; Audit Tenur; Auditors' Specialization; Audit Deficiencies; PPPK.

\begin{abstract}
Abstrak
Pengaruh Workload, Masa Perikatan Audit, dan Spesialisasi Auditor Terhadap Defisiensi Audit Pada KAP Yang Digunakan Oleh Perusahaan Manufaktur Yang Terdaftar di BEI tahun 2015-2018 Penelitian ini bertujuan untuk menguji pengatuh workload, masa perikatan audit, spesialisasi auditor terhadap defisiensi audit yang dilakukan oleh kantor akuntan publik yang diidentifikasi oleh Pusat Pembinaan Profesi Keuangan (PPPK) Kementerian Keuangan RI. Populasi dalam penelitian ini sebanyak 40 KAP dan 34 sampel data yang diperoleh melalui metode purposive sampling. Workload diukur dengan rasio perbandingan antara jumlah klien dengan jumlah partner audit. Masa perikatan audit dihitung menggunakan skala interval. Spesialisasi auditor dihitung dengan variabel dummy. Sedangkan hasil dari defisiensi audit dilihat dari laporan hasil pemeriksaan PPPK terhadap KAP. Penelitian ini merupakan penelitian kuantitatif yang menggunakan teknik analisis regresi linier berganda. Hasil penelitian menunjukkan bahwa variabel workload dan masa perikatan audit berpengaruh positif terhadap defisiensi audit. Spesialisasi auditor berpengaruh negatif terhadap defisiensi audit.
\end{abstract}

Kata Kunci: Audit; Workload; Masa Perikatan Audit; Spesialisasi Auditor; Defisiensi Audit; PPPK

\section{PENDAHULUAN}

Perusahaan di Indonesia pada saat ini sedang berkembang pesat, perkembangan tersebut juga diiringi dengan bertambahnya jumlah Akuntan Publik (AP) dan Kantor Akuntan Publik (KAP) yang semakin meningkat setiap tahunnya.Guna menghindari adanya persaingan yang mungkin terjadi, perusahaan harus mampu menunjukkan kualitas perusahaannya terhadap publik dengan menyajikan laporan keuangan yang baik. Selain itu, laporan keuangan yang disajikan harus terbebas dari berbagai kekeliruan ataupun kecurangan yang mengakibatkankesalahan material. Kesalahan-kesalahan tersebut harus dihindari karena laporan keuangan merupakan jendela informasi yang digunakan para pengguna sebagai bahan pertimbangan dan acuan dalam pengambilan sebuah keputusan.Demi tercapainya hal tersebut, perusahaan membutuhkan pihak ketiga yang independen untuk melakukan audit laporan keuangannya. 
Kegagalan dalam melaksanakan audit berkualitas dapat membawa petaka bagi pihak auditor maupun pihak klien. Salah satu contoh adalah kasus Enron Corporation dan KAP Arthur Andersen di Amerika yang terjadi pada tahun 2001. Kasus tersebut merupakan kasus kegagalan audit terbesar danmenarik perhatian banyak pihak. Laporan keuangan Enron diaudit oleh KAP Arthur Endersen selama hampir 20 tahun dan dinyatakan wajar tanpa pengecualian. Pada tanggal 2 Desember 2001 Enron Corporation dinyatakan pailit, hal tersebut menyebabkan tanda tanya besar bahwa Enron dan Arthur Andersen telah bekerja sama dalam konspirasi ini secara sengaja atautidak sengaja.

Kasus serupa juga terjadi di Indonesia, Pusat Pembinaan Profesi Keuangan (PPPK) menemukan pelanggaran yang dilakukan oleh AP atau auditor KAP. Permasalahan yang terjadi dalam kasus ini yaitu pada tahun 2018 PT Garuda Indonesia (Persero) Tbk. melakukan kesalahan khususnya pada pengakuan pendapatan yang dihasilkan dari PT Mahata Aero Teknologi atas perjanjian kerja sama yangdisajikan tidak sesuai dengan standar akuntansi (Kementerian Keuangan, 2019). PT Garuda Indonesia melaporkan laba bersih sebesar USD 809,85 ribu pada laporan keuangan tahun 2018, berbanding terbalik dengan kondisi 2017 yang merugi sebesar USD 216,58 juta. KAP Tanubrata, Sutanto, Fahmi, Bambang \& Rekan khususnya AP Kasner Sirumapea merupakan salah satu KAP yang mengaudit laporan keuangan PT Garuda Indonesia.Kemenkeu menjatuhkan sanksi bagi AP Kasner yaitu pembekuan izin selama 12 bulan dan sanksi bagi KAP Tanubrata, Sutanto, Fahmi, Bambang \& Rekan yaitu sanksi administratif berupa peringatan tertulis untuk melakukanpembenahanpada sistem pengendalian mutu.

Adapun fenomena yang terjadi pada KAP yang diawasi dan diperiksa oleh PPPK yaitu masih banyak KAP yang melanggar aturan-aturan selama melakukan peroses audit yang menyebabkan adanya kegagalan audit atau defisiensi audit. PPPK merupakan otoritas yang diberikan wewenang untuk memeriksa dan mencegah terjadinya defisiensi audit di Indonesia. PPPK mempunyai tugas untuk melakukan pembinaan, pengembangan dan pengawasan terhadap jasa profesi Akuntan, Akuntan Publik, Teknisi Akuntansi, Penilai, Penilai Publik, dan Aktuaris yang dinyatakan pada Peraturan Menteri Keuangan Nomor 206/PMK.01/2014 (2014)Tentang Organisasi dan Tata Kerja Kementerian Keuangan.

Keberadaan PPPK dapat membantu perusahaan-perusahaan besar terutama dalam sektor manufaktur untuk memilih KAP yang baik dan terbebas dari histori skandal audit. Selain itu keberadaan PPPK sebagai pembina dan pengawas diharapkan dapat meminimalisir terjadinya kasuskasus audit di Indonesia dan pelanggaran-pelanggaran yang mungkin dilakukan oleh auditor independen.

Adanya pelanggaran yang terjadi selama proses audit diduga terjadi karena workload suatu KAP yang tinggi, sehingga menyebabkan kelelahan bagi auditor dan menurunkan kemampuan auditor untuk menemukan kekeliruan maupun penyimpangan yang terdapat pada laporan keuangan. Hal lain yang diduga memicu adanya pelanggaran audit adalah masa perikatan audit. Karena hal tersebut, pemerintah membuat aturan yang mengatur masa perikatan audit di Indonesia yang dapat ditemukan dalam Keputusan Menteri Keuangan Republik Indonesia Nomor 359/KMK.06/2003, 2003tentang jasa Akuntan Publik yang membatasi masa perikatan audit AP yaitu tiga tahun buku berturut-turut dan masa perikatan audit KAP adalah lima tahun buku berturut-turut. Peraturan tersebut kembali diubah menjadi Peraturan Menteri Keuangan Republik Indonesia PMK/17.01/2018, 2008dimana pembatasan pemberian jasa KAP diperpanjang menjadi enam tahun berturutturut.Peraturan tersebut dibuat untuk menghindari adanya kecurangan yang terjadi saat melakukan audit laporan keuangan yang melibatkan auditor dan mengakibatkan menurunnya independensi auditor karena masa perikatan audit yang terlalu lama.

Selain dua hal tersebut, faktor lain yang diduga dapat menyebabkan adanya kegagalan atau defisiensi audit yaitu spesialisasi auditor. Penelitian (Balsam et al., 2003) menemukanperusahaan yang diaudit oleh auditor yang memiliki spesialisasi dibidang tertentu akan memiliki nilai akrual diskresioner yang lebih rendah. Hal tersebut karena auditor spesialis memiliki lebih banyak pengetahuan dan pemahaman mengenairisiko bisnis perusahaan, risiko audit pada industrinya, daninternal kontrol perusahaan tersebut (Setiawan W. \& Fitriany, 2011).

Perusahaan manufaktur yang terdaftar di BEI dipilih sebagai objek penelitian karena perusahaan manufaktur merupakan perusahaan yang memiliki kompleksitas yang tinggi dalam kegiatan operasional perusahaan sehingga dibutuhkan auditor independen yang mengetahui sektor manufaktur dengan baik untuk melakukan audit laporan keuangan perusahaan tersebut agar terhindar dari indikasi kesalahan maupun kecurangan. 

yang digunakan oleh Perusahaan Manufaktur yang Terdaftar di BEI Tahun 2015-2018

Penelitian sebelumnya terkait beban kerja diantaranya dilakukan oleh Rusli \& Wiratmaja (2016). Penelitian tersebut melihat beban kerja terhadap kualitas audit dalam level AP atau partner KAP. Penelitian ini juga menggunakan pengukuran dalam level AP, hal tersebut digunakan agar dapat mengetahui jumlah klien yang riil ditangani oleh AP. Selanjutnya, penelitian terkait dengan masa perikatan audit diantaranya dilakukan oleh Febriyanti \& Mertha (2014). Namun, pengaruh masa perikatan audit dalam penelitian tersebut menggunakan perusahaan manufaktur yang tedaftar di BEI sebagai sampel penelitiannya. Penelitian terkait pengaruh spesialisasi auditor diantaranya dilakukan oleh Ishak et al. (2015). Pengukuran variabel ini bertujuan untuk mengkaji apakah auditor yang memiliki spesialisasi dalam bidang tertentu akan menghasilkan kualitas audit yang lebih baik dibanding dengan auditor yang tidak memiliki spesialisasi.

Penelitian terkait beban kerja terhadap defisiensi audit diantaranya dilakukan oleh Yoga \& Dinarjito (2019). Penelitian ini bertujuan untuk mengetahui pengaruh beban kerja terhadap defisiensi audit yang diidentifikasi PPPK. Adapun defisiensi audit diukur dengan temuan hasil pemeriksaan PPPK. Hasil penelitian tersebut menyatakan beban kerja tidak berpengaruh terhadap defisiensi audit. Hal tersebut diduga karena akuntan publik berupaya untuk tetap menjaga reputasinya.

\section{KAJIAN PUSTAKA}

\section{Teori Keagenan}

Nuratama (2011) menyebutkan teori keagenan berusahauntuk mengatasi masalah keagenan yang tercipta karena perbedaan tujuan antara pihak-pihak yang bekerja sama. Hubungan keagenan muncul karena adanya suatu kontrak kerja yang telah disepakati bersama antara manajemen yang disebut sebagai agent maupun pemilik perusahaan yang disebut sebagai principal. Berdasarkan pendelegasian wewenang, pemilik perusahaan memberikan wewenang kepada pihak manajemen untuk mengelola perusahaan dan membuat keputusan mengenai perusahaan terhadap kepentingan pemilik dan di akhir periode manajemen juga memiliki kewajiban untuk membuat laporan kinerja perusahaan dalam bentuk laporan keuangan bagi pemilik perusahaan.

Kepentingan antara pihak manajemen dan pemilik perusahaan tidaklah selalu sejalan. Masalah keagenan timbul dikarenakan informasi yang dimiliki pihak manajemen lebih banyak mengenai perusahaan, hal tersebut dapat memicu adanya asimetry information. Bagi pemilik perusahaan akan sulit untuk memastikan apakah manajemen telah melakukan sesuatu secara tepat karena terbatasnya informasi yang dimiliki. Adanya kecenderungan setiap pihak untuk memperoleh tingkat kemakmuran yang dikehendakinya dapat memicu praktik earnings management (Salno \& Baridwan, 2000).

Praptitorini \& Januarti (2011) mengemukakan bahwa pemilik perusahaan memerlukan adanya pihak ketiga yang independen sebagai mediator antara pemilik perusahaan dan manajemen. Auditor juga berguna untuk memonitor perilaku pihak manajemen agar bertindak sesuai dengan kepentingan pemilik perusahaan (principal).

Dari penjelasan diatas dapat disimpulkan bahwa teori agensi merupakan teori yang digunakan untuk mengatasi masalah-masalah yang timbul antara agent dan principal akibat adanya kecenderungan setiap pihak yang ingin mencapai tingkat kemakmuran yang dikehendakinya. Masalah-masalah yang terjadi dapat dihindari dengan adanya pihak ketiga yang independen yakni auditor yang berguna sebagai mediator antara pemilik perusahaan dan manajemen.

\section{Teori Atribusi}

Robbins (2001) mengemukakan mengenai teori yang menjelaskan perilaku atau karakter seseorang dalam melaksanakan suatu tugas yang mungkin diakibatkan oleh faktor internal maupun eksternal. Dalam melaksanakan tugas sebagai auditor independen, laporan hasil audit seharusnya dilaporkan sesuai dengan temuan-temuan yang ada pada laporan keuangan. Namun dalam beberapa kasus, laporan hasil audit seringkali tidak sesuai dengan yang sebenarnya terjadi. Hal tersebut terjadi karena seorang auditor dipengaruhi oleh beberapa faktor internal maupun eksternal.

Perilaku seseorang yang dipengaruhi oleh faktor internal merupakan perilaku yang terjadi dibawah kendali seorang auditor yang berpengaruh terhadap pemberian suatu penilaian. Dalam hal ini, sikap independesi seorang auditor sangat diperlukan untuk menghindari hal-hal menyimpang yang mungkin terjadi saat melakukan audit laporan keuangan. Selain itu, faktor eksternal juga dapat mempengaruhi seorang auditor saat menentukan opini audit. Salah satu faktor eksternal yang dapat 
mempengaruhi seorang auditor adalah masa perikatan audit.Perikatan audit yang terlalu lama menyebabkan auditor kehilangan independensi karena timbulnya keakraban yang berlebihan.

Dari penjelasan diatas dapat disimpulkan bahwa teori atribusi merupakan teori yang digunakan untuk mengetahui penyebab terjadinya penyimpangan yang dilakukan auditor saat melakukan audit laporan keuangan. Masalah-masalah yang mungkin terjadi baik karena pengaruh internal maupun eksternal dapat dihindari dengan adanya spesialisasi auditor, karena semakin tinggi spesialisasi atau kompetensi yang dimiliki seorang auditor maka kemampuan untuk merencanakan audit menjadi lebih baik.

\section{Good Corporate Governance}

Forum for Corporate Governance in Indonesia atau FCGI dalam (Rusli \& Wiratmaja, 2016) menjelaskan Good Corporate Governanceyaitu peraturan yang mengatur hubungan yang terjadi antarapemegang saham, pengelola perusahaan, pemerintah, pihak kreditur,karyawan, dan para pemangku kepentingan internal dan eksternal lainnya yang berhubungan dengan hak dan kewajiban mereka atau suatu sistem mengendalikan atau mengarahkan suatu perusahaan.

Komite Nasional Kebijakan Governance atau KNKG (2006) mendefinisikan Good Corporate Governance sebagai struktur yang bisa digunakan oleh perusahaan guna memberikan nilai tambah kepadapihak-pihak yang berkepentingan secara berkesinambungan.

Berdasarkan definisi tersebut, GCG merupakan seperangkat peraturan yang mengatur hubungan antara pihak-pihak yang berkepentingan untuk mencegah terjadinya kesalahan dan untuk memastikan bahwa kesalahan tersebut dapat segera diatasi dan diperbaiki.

\section{Standar Audit}

Arens et al. (2003) menyebutkan standar audit merupakan pedoman audit yang harus diikuti oleh auditor pada saat melakukan audit untuk memahami tanggung jawab profesionalnya dalam audit laporan keuangan. Standar audit menurut Ikatan Akuntan Indonesia (IAI) terdiri dari sepuluh standar yang kemudian dikelompokkan menjadi tiga kelompok besar, yaitu standar umum, standar pekerjaan lapangan, dan standar pelaporan beserta interpretasinya.

Standar audit kemudian diubah menjadi International Standards on Auditing (ISA). Sari \& Rustiana (2016) menyebutkan International Standards on A uditing (ISA) merupakan standar audit terbaru yang telah diadopsi di Indonesia. Aplikasi ISA diterapkan melalui revisi terhadap Standar Profesional Akuntan Publik (SPAP). Standar audit dalam penerapannya yang berbasis ISA berlaku efektif untuk audit atas laporan keuangan terhitung mulai tanggal 1 Januari 2013 untuk emiten dan pada 1 Januari 2014 untuk entitas non emiten.

Tuannakota (2013) menjelaskan Penerapan ISA sebagai standar baru akan memberikan nilai tambah bagi para investor dan calon investor yang akan memperoleh laporan keuangan yang lebih baik dengan standar baru. Selain itu, profesi akuntansi di Indonesia juga akan mendapatkan manfaat yang besar, yakni profesi akuntansi mendapatkan nilai tambah yang tidak berwujud berupa peningkatan mutu audit.

Perubahan standar audit antara ISA dengan standar terdahulu bukanlah perubahan tanpa makna. Beberapa profesi akuntan berpendapat bahwa perubahan standar audit bersifat substantif dan mendasar. ISA memberikan penekanan yang sangat besar terhadap faktor risiko sejak auditor mempertimbangkan untuk menerima atau menolak suatu entitas dalam penugasan auditnya sampai setelah menerbitkan laporan yang berisi opininya.

\section{Workload}

Hansen et al. (2007) mengibaratkan workload sebagai audit capacity stress yaitu tekanan yang dihadapi oleh auditor terkait jumlah klien audit yang ditanganinya. Workload menunjukkan beban kerja seorang auditor yang dinilai dari jumlah klien dan tuntutan tugas yang perlu diselesaikan dalam jangka waktu tertentu pada saat melakukan proses audit.

López \& Peters (2012) mendefinisikan workload sebagai busy season yang terjadi pada periode kuartal pertama awal tahun. Hal tersebut terjadi karena banyak perusahaan yang memiliki tahun tutup buku atau fiscal years yang berakhir pada bulan Desember.Tingginya jumlah klien yang diaudit dan banyaknya kasus yang harus diselesaikan oleh seorang auditor menyebabkan menurunnya kemampuan auditor untuk mendeteksi kecurangan. Selain itu, beratnya tekanan beban 
kerja juga dapat menimbulkan dampak yang buruk bagi proses audit, antara lain auditor cenderung mengurangi beberapa prosedur audit untuk mempersingkat waktu proses audit (López \& Peters, 2012).

Jadi dari definisi diatas dapat disimpulkan bahwa workload merupakan beban kerja yang dihadapi oleh auditor menjelang tahun tutup buku yang berakhir pada bulan Desember, beban kerja seorang auditor dapat dinilai dari jumlah klien, banyaknya kasus dan batas waktu yang tersedia dalam melakukan proses audit.

\section{Masa Perikatan Audit}

Masa perikatan audit merupakan lama hubungan kerja antara auditor dengan kliennya dalam hal pemeriksaan laporan keuangan. Hal ini diatur dalam Keputusan Menteri Keuangan Republik Indonesia Nomor 359/KMK.06/2003 (2003) tentang Jasa Akuntan Publik yang membatasi pemberian jasa audit AP yaitu tiga tahun buku berturut-turut sedangkan bagi KAP lima tahun buku beturut-turut.

Peraturan tersebut dibuat untuk menghindari adanya kecurangan dalam hal laporan keuangan yang terjadi pada saat melakukan proses audit. Pada tanggal 5 Februari 2008, peraturan ini diganti dengan Peraturan Menteri Keuangan Republik Indonesia PMK/17.01/2018 (2008) dimana pemberian jasa audit KAP diperpanjang menjadi enam tahun berturut-turut.

(Johnson et al., 2002), membagi jasa masa perikatan audit menjadi tiga kategori, ketegori ini dibedakan berdasarkan lama terjadinya masa perserikatan audit. Kategori yang pertama yaitu pendek, dimana masa perikatan terjadi dua sampai tiga tahun.Kategori kedua yaitu sedang dimana masa perikatan terjadi empat sampai delapan tahun. Kategori ketiga adalah panjang, yaitu masa perikatan terjadi lebih dari delapan tahun.

Dari pemaparan diatas, dapat dijelaskan bahwa masa perikatan audit adalah rentang waktu hubungan kerja antara auditor dengan kliennya. Masa perikatan audit merupakan hal yang dapat mempengaruhi independensi seorang auditor. Karena semakin lama masa perikatan audit dapat menyebabkan adanya hubungan khusus yang dapat menimbulkan keakraban antara auditor dan klien.

\section{Spesialisasi Auditor}

(Siregar, 2016) menyebutkan spesialisasi auditor merupakan auditor yang mempunyai pemahaman dan pengetahuan yang spesifik tentang industri tertentu sehingga dapat memahami karakteristik perusahaan dalam industri tertentu secara lebih kompherensif. Auditor dapat dikatakan sebagai spesialis apabila auditor ikut serta dalam pelatihan yang berpusat pada suatu industri tertentu.

(Balsam et al., 2003) menjelaskanbahwa perusahaan yang diaudit oleh auditor yang memiliki spesialisasi dibidang tertentu akan memiliki nilai akrual diskresioner yang lebih rendah daripadaauditor yang tidak mempunyai spesialisasi. Hal tersebut terjadi karena auditor dengan spesialis tertentu pasti mempunyai pemahaman yang lebih spesifik terkait industri tersebut.

Pengetahuan yang harus dimiliki oleh auditor bukan hanya hal terkait audit dan akuntansi, melainkan auditor juga harus memahami jenis industri kliennya. Walaupun prinsip-prinsip berbagai industri memiliki beberapa kesamaan, namun tentu saja terdapat beberapa perbedaan dari yang dapat dilihat dari beberapa aspek, yaitu segi operasional perusahaan, prinsip akuntansi yang digunakan, tata cara perhitungan pajak dan hal lainnya.

Dapat disimpulkan bahwa auditor spesialis lebih memungkinkan untuk menemukan kesalahan dan mendeteksi adanya kecurangan dibandingkan auditor non spesialis. Pengetahuan auditor spesialis sangat dibutuhkan untuk menghindari adanya defisiensi audit.

\section{Defisiensi Audit}

(Yoga \& Dinarjito, 2019) menyebutkan defisiensi audit merupakan kegagalan auditor untuk memenuhi secara keseluruhan persyaratan audit yang berlaku umum di Indonesia yaitu Standar Profesional Akuntan Publik (SPAP). Defisiensi auditor independen saat melakukan proses audit suatu perusahaan dapat menyebabkan sikap skeptis pada masyarakat.

Chang et al. (2017) (Aobdia \& Petacchi, 2018) menyatakan defisiensi audit adalah kegagalan AP dan KAP untuk menemukan adanya kecurangan atau menyatakan dengan tepat kesalahan dalam laporan keuangan, termasuk kegagalan dalam melaksanakan persyaratan untuk melakukan pengungkapan, serta kegagalan AP dan KAP untuk melaksanakan proses audit dengan memadai prosedur audit tertentu yang diperlukan. 
Jadi dapat disimpulkan bahwa defisiensi audit merupakan kegagalan pada saat melakukan audit laporan keuangan oleh auditor independen karena auditor tidak dapat memenuhi standar audit yang berlaku umum di Indonesia. Kegagalan dalam proses audit juga bisa disebabkan oleh kecurangan. Kecurangan merupakan hal yang sulit untuk dihindari karena di satu pihak auditor harus memberikan opini mengenai kewajaran laporan keuangan, di sisi lain auditor juga harus bisa memenuhi tuntutan dan keinginan klien yang telah membayar fee agar kliennya merasa puas dengan pekerjaannya dan tetap menggunakan jasanya di periode selanjutnya.

\section{Hipothesis}

(Hansen et al., 2007) mengibaratkan workload sebagai audit capacity stress yaitu tekanan yang dihadapi oleh auditor terkait jumlah klien audit yang ditanganinya. Workload menunjukkan beban kerja yang dihadapi oleh seorang auditor yang dapat dinilai dari jumlah klien dan tuntutan tugas yang harus diselesaikan dalam jangka waktu tertentu pada saat melakukan proses audit.

Tingginya jumlah klien yang diaudit dan banyaknya kasus yang harus diselesaikan oleh seorang auditor menyebabkan menurunnya kemampuan auditor untuk mendeteksi kecurangan. Selain itu tekanan beban kerja yang sangat berat juga dapat menimbulkan dampak yang buruk bagi proses audit, antara lain auditor cenderung mengurangi beberapa prosedur audit untuk mempersingkat waktu proses audit (López \& Peters, 2012).

Penelitian Yoga \& Dinarjito (2019) menemukan bahwa workload terbukti tidak berpengaruh terhadap defisiensi audit karena akuntan publik didukung oleh tim audit yang kompeten. Tim audit yang kompeten mempunyai kemampuan dalam merencanakan audit dengan baik. Berbeda dengan penelitian Rusli \& Wiratmaja (2016) dan Ishak et al. (2015) penelitian ini menyatakan bahwa workload berpengaruh negatif terhadap kualitas audit, hal ini berarti semakin tinggi workload, maka kualitas audit akan semakin buruk sehingga potensi terjadinya defisiensi audit akan menigkat.

$\mathrm{H}_{1}$ : Workload berpengaruh positif terhadap defisiensi audit pada KAP yang digunakan oleh perusahaan manufaktur yang terdaftar di BEI tahun 2015-2018

Masa perikatan audit merupakan lama hubungan kerja antara auditor dengan kliennya dalam hal pemeriksaan laporan keuangan. Hal ini diatur dalamKeputusan Menteri Keuangan Republik Indonesia Nomor 359/KMK.06/2003 (2003) tentang Jasa Akuntan Publik yang membatasi pemberian jasa audit AP yaitu tiga tahun buku berturut-turut sedangkan bagi KAP yaitu lima tahun buku beturut -turut. Peraturan tersebut dibuat untuk menghindari adanya kecurangan dalam hal laporan keuangan yang terjadi pada saat melakukan proses audit. Pada tanggal 5 Februari 2008, peraturan ini diganti dengan Peraturan Menteri Keuangan Republik Indonesia PMK/17.01/2018(2008) dimana pemberian jasa audit KAP diperpanjang menjadi enam tahun berturut-turut.

Berbagai pendapat muncul dalam penelitian mengenai hubungan pengaruh masa perikatan audit dan defisiensi audit. Ada pihak yang menilai bahwa masa perikatan audit yang panjang akan menimbulkan terjadinya defisiensi audit karena menurunnya independensi auditor akibat timbulnya hubungan yang akrab antara auditor dan klien. Selain itu, pendapat lain menyebutkan bahwa semakin panjang perikatan audit akan menciptakan pengetahuan bisnis bagi seorang auditor yang dapat digunakan untuk merancang program audit yang efektif dan mampu menyediakan informasi yang dapat dipercaya dalam laporan keuangan.

Febriyanti \& Mertha (2014) menemukan bahwa masa perikatan audit berpengaruh negatif pada kualitas audit, hal tersebut berarti semakin lama masa perikatan audit sehingga berpotensi menimbulkan defisiensi audit yang lebih banyak. Penelitian Rusli \& Wiratmaja (2016) mengemukakan bahwa pengaruh positif antara masa perikatan audit dan kualitas audit disebabkan karena KAP semakin mengenal klien dan memiliki pengetahuan yang lebih baik mengenai proses bisnis klien sehingga dapat merancang prosedur audit yang lebih efektif. Hal tersebut mengakibatkan timbulnya defisiensi audit menjadi lebih rendah.

$\mathrm{H}_{2}$ : Masa perikatan audit berpengaruh positif terhadap defisiensi audit pada KAP yang digunakan oleh perusahaan manufaktur yang terdaftar di BEI tahun 2015-2018

Siregar (2016) menyebutkan spesialisasi auditor merupakan auditor yang memiliki pemahaman dan pengetahuan yang spesifik tentang industri tertentu sehingga dapat memahami karakteristik perusahaan dalam industri tertentu secara lebih kompherensif. Auditor dapat dikatakan sebagai spesialis apabila auditor telah mengikuti pelatihan-pelatihan yang berfokus pada suatu industri tertentu. 

yang digunakan oleh Perusahaan Manufaktur yang Terdaftar di BEI Tahun 2015-2018

Spesialisasi auditor dalam industri tertentu dapat membentuk auditor tesebut untuk memiliki kemampuan dan pengetahuan yang lebih dibanding auditor non spesialis. Bayaknya AP dan KAP yang ada saat ini tentu memudahkan perusahaan untuk melakukan audit laporan keuangan, akan tetapi apabila proses audit dilakukan oleh auditor non spesialis maka akan meningkatkan kemungkinan terjadinya defisiensi audit.

Pengetahuan yang harus dimiliki oleh auditor bukan hanya hal terkait audit dan akuntansi, melainkan auditor juga harus memahami jenis industri kliennya. Walaupun prinsip-prinsip berbagai industri memiliki beberapa kesamaan, namun tentu saja terdapat beberapa perbedaan yang dapat dilihat dari beberapa aspek, yaitu segi operasional perusahaan, prinsip akuntansi yang digunakan, tata cara perhitungan pajak dan hal lainnya.

Ishak et al.(2015) menyatakan spesialisasi auditor berpengaruh positif pada kualitas audit, artinya semakin meningkat spesialisasi yang dimiliki oleh akuntan publik akan meningkatkan kualitas audit, yang artinya semakin tinggi tingkat spesialisasi, maka kemungkinan terjadinya defisiensi audit semakin rendah.

$\mathrm{H}_{3}$ : Spesialisasi auditor berpengaruh negatif terhadap defisiensi audit pada KAP yang digunakan oleh perusahaan manufaktur yang terdaftar di BEI tahun 2015-2018

\section{METODE}

Data yang digunakan dalam penelitan ini adalah data dari hasil pemeriksaan terhadap KAP oleh PPPK tahun 2015-2018. Data lain yang digunakan adalah data klien dan partner KAP yang diterbitkan oleh PPPK beserta data perikatan audit yang terdapat pada laporan keuangan tahunan perusahaan manufaktur yang diterbitkan oleh BEI.

Dalam penelitian ini menggunakan sampel yang dipilih dengan teknik purposive sampling, menggunakan kriteria pemilihan sampel 1) Perusahaan manufaktur yang terdaftar di BEI diaudit oleh KAP yang diperiksa oleh PPPK tahun 2015-2018. 2) Perusahaan yang diaudit menyajikan laporan keuangan dalam rupiah. 3) Untuk KAP yang mengaudit satu perusahaan, maka perusahaan tersebut langsung dijadikan sampel. 4) Untuk KAP yang mengaudit beberapa perusahaan manufaktur, maka dipilih perusahaan yang memiliki aset terbesar. 5) Seluruh data yang diperlukan terkait jumlah temuan hasil pemeriksaan PPPK, jumlah klien kantor akuntan publik, serta data perikatan audit bagi kantor akuntan publik yang dijadikan sampel pemeriksaan tersedia secara lengkap.

Terkait variabel penelitan, workload seorang akuntan publik merupakan banyak klien dari seorang auditor dalam satu tahun. Tidak semua KAP di Indonesia diperiksa oleh PPPKkarena pemeriksaan KAP dilakukan degan cara sampel, sehingga workload dalam penelitian ini diukur dengan banyaknya jumlah klien audit umum pada KAP yang dijadikan sampel pemeriksaan perikatan audit dalam satu tahun berdasarkan laporan KAP.

Masa perikatan audit merupakan lamanya hubungan pekerjaan audit yang terjalin antara auditor dan klien.Masa perikatan audit diukur dengan melihat tahun ke-n klien tersebut diaudit oleh KAP yang sama yang dijadikan sampel pemeriksaan.

Spesialisasi auditor menunjukkan apakah KAP yang mengaudit perusahaan manufaktur memiliki kemampuan atau spesialisasi dalam industri manufaktur. Spesialisasi diproksikan dengan menggunakan auditor industry specialization yang diukur menggunakan variabel dummy. Auditor yang memiliki spesialisasi industri akan diberikan nilai 1, auditor non spesialis akan diberikan nilai 0 .

Defisiensi audit pada KAP merupakan defisiensi yang diidentifikasi oleh PPPK yang didapat dari temuan hasil pemeriksaan berkala PPPK terhadap KAP atas laporan keuangan yang tercantum dalam laporan hasil pemeriksaan PPPK. Defisiensi audit dalam penelitian ini merupakan kegagalan auditor suatu KAP dalam memenuhi persyaratan standar audit yang berlaku umum di Indonesia yaitu Standar Profesional Akuntan Publik (SPAP).

Adapun model dalam penelitian ini adalah sebagai berikut:

$Y=a+\beta 1 X 1+\beta 2 X_{2}+\beta 3 X_{3}+e$

Penelitian ini menggunakan teknik analisis regresi linier berganda. Sebelum menganalisi hipotesis, dilakukan uji asumsi klasik yang terdiri dari uji normalitas, uji multikolinearitas, uji autokorelasi, dan uji heteroskedasitas. Selanjutnya dilakukan analasis regresi yaitu koefisien 

yang digunakan oleh Perusahaan Manufaktur yang Terdaftar di BEI Tahun 2015-2018

determinasi $\left(\mathrm{R}^{2}\right)$, uji statistik $\mathrm{F}$, uji statistik t.

\section{HASIL DAN PEMBAHASAN}

Objek penelitian ini adalah defisiensi audit yang diidentifikasi oleh PPPK Kementerian Keuangan RI yang dilakukan KAP pada saat melakukan audit perusahaan manufaktur yang terdaftar di Bursa Efek Indonesia (BEI). Pemilihan perusahaan manufaktur karena perusahaan manufaktur memiliki kompleksitas yang tinggi dalam kegiatan operasional perusahaannya sehingga meningkatkan peluang terjadinya tindakan akrual yang dapat mempengaruhi hasil audit yang disajikan oleh auditor independen. Penggunaan satu jenis sektor industri dilakukan untuk menghindari industrial effect atau risiko bias yang mungkin disebabkan oleh adanya perbedaan industri. Dipilihnya tahun 2018 sebagai tahun akhir penelitian dikarenakan tahun 2018 merupakan tahun terbaru dimana laporan seluruh KAP telah diperiksa PPPK Kementerian Keuangan RI.

Penelitian ini memakai analisis statistik deskriptif sebagai pendeskripsian data penelitian. Setiap variabel terikat maupun variabel bebas akan dilihat nilai nilai rata-rata (mean), minimum, maksimum, dan standar deviasinya. Hasil dari analisis statistik deskriptif untuk tiap-tiap variabel dapat dilihat pada Tabel 1.

Tabel 1

Hasil Statistik Deskriptif

\begin{tabular}{cccccc}
\hline & $\mathrm{N}$ & Minimum & Maximum & Mean & Std. Deviation \\
\hline Workload (X1) & 34 & 4.00 & 105.00 & 46.2941 & 25.17638 \\
Masa Perikatan Audit (X2) & 34 & 1.00 & 4.00 & 2.3529 & 1.20309 \\
Spesialisasi (X3) & 34 & .00 & 1.00 & .6176 & .49327 \\
Defisiensi Audit (Y) & 34 & .00 & 8.00 & 1.1765 & 1.88246 \\
Valid N (listwise) & 34 & & & & \\
\hline
\end{tabular}

Berdasarkan Tabel 1 dapat dilihat variabel workload memiliki nilai minimum 4,00 dan nilai maksimum 105,00 ini berarti beban kerja terendah bagi partner KAP yang diperiksa PPPK dalam 1 tahun adalah sebanyak 4 klien audit dan beban kerja tertinggi yang dipikul seorang partner KAP yang diperiksa PPPK dalam satu tahun adalah 105 klien audit.

Variabel masa perikatan audit memiliki nilai minimum 1, sedangkan nilai maksimumnya adalah 4. Nilai tersebut memiliki arti bahwa pengamatan yang dilakukan selama 4 tahun diketahui bahwa perikatan terendah yang terjadi antara KAP dan kliennya adalah 1 tahun, sedangkan perikatan tertinggi antara KAP dengan kliennya adalah 4 tahun.

Variabel spesialisasi auditor diukur dengan variable dummy, dimana nilai 1 akan diberikan untuk auditor yang memiliki spesialisasi industri, dan nilai 0 diberikan untuk auditor yang tidak memiliki spesialisasi. Hasil pengamatan selama periode 1 tahun menunjukkan nilai minimum 0 yang berarti perusahaan tersebut diaudit oleh KAP non spesialis sedangkan nilai maksimum 1 menunjukkan bahwa perusahaan tersebut diaudit oleh KAP yang mempunyai spesialisasi auditor.

Variabel terikat defisiensi audit memiliki nilai terendah 0 berarti bahwa kantor akuntan publik telah seluruhnya taat terhadap Standar Profesional Akuntan Publik, sedangkan nilai tertinggi 8 menunjukkan bahwa jumlah temuan terbanyak atas kantor akuntan publik yang diperiksa PPPK adalah 8 temuan.

Selanjutnya, terlebih dahulu dilakukan uji asumsi klasik sebelum melakukan pengujian hipotesis. Uji normalitas berfungsiuntuk mendeteksi normalitas data dengan menggunakan uji Kolmogorov-Smirnov. Hasil pengujian pada persamaan regresi linear berganda dalam Tabel 2 menunjukkan bahwa nilai Asymp. Sig (2-tailed) 0,195 lebih besar dari level of significant, yaitu 5\% $(0,05)$. Jadi dapat diambil kesimpulan bahwa nilai residual pada model regresi yang diuji sudah berdistribusi normal.

Uji multikorelasi dapat dilihat pada nilai tolerance dan nilai variance inflation factor $(V I F)$.Variabel dapat dikatakan terbebas dari multikolinearitas, jika nilai tolerancepada setiap variabel lebih dari $10 \%$ atau VIF kurang dari 10. Pengujian untuk tiap-tiap variabel bebasmemperoleh nilai tolerance di atas 0,10 dan VIF nya kurang dari 10 sehingga disimpulkan tidak terjadi multikoleniaritas dalam model regresi.

Uji autokorelasi dilakukan untuk melacak adanya korelasi data dari tahun $\mathrm{t}$ dengan tahun $\mathrm{t}-1$ 
(sebelumnya). Hasil uji autokorelasi yang diperoleh adalah 1,6519<2,082<2,348, maka dapat disimpulkan bahwa model regresi dengan uji durbin watson sudah memenuhi kriteria du $<\mathrm{DW}<4$-du, sehingga data dikatakan bebas uji autokorelasi.

Uji heteroskedastisitas pada penelitian ini menggunakan uji Glejser. Uji Glejser dilakukan dengan cara meregresi nilai absoluteresidual dari model yang diestimasi terhadap variabel bebas. Nilai signifikansi Workload $\left(\mathrm{X}_{1}\right)$ sebesar 0,398, Masa perikatan audit $\left(\mathrm{X}_{2}\right)$ sebesar 0,095, dan Spesialisasi $\left(\mathrm{X}_{3}\right)$ sebesar 0,244 . Hasil uji tersebut memiliki nilai yang lebih besar dari $\alpha=0,05$. Oleh karena itu, dapat disimpulkan bahwa tidak terjadi heteroskedastisitas.

Tabel 2

Koefisien Regresi Linier Berganda

\begin{tabular}{|c|c|c|c|c|c|c|}
\hline & \multirow[t]{2}{*}{ Model } & \multicolumn{2}{|c|}{ Unstandardized Coefficients } & \multirow{2}{*}{$\begin{array}{c}\text { Standardized } \\
\text { Coefficients } \\
\text { Beta } \\
\end{array}$} & \multirow[t]{2}{*}{$\mathrm{t}$} & \multirow[t]{2}{*}{ Sig. } \\
\hline & & $\mathrm{B}$ & Std. Error & & & \\
\hline \multirow{7}{*}{1} & (Constant) & -.673 & .701 & & -.960 & .345 \\
\hline & Workload & .035 & .010 & .464 & 3.524 & .001 \\
\hline & Masa Perikatan Audit & .430 & .206 & .275 & 2.087 & .046 \\
\hline & Spesialisasi & -1.245 & .479 & -.326 & -2.601 & .014 \\
\hline & Adjusted R Square & 0.492 & & & & \\
\hline & $\mathrm{F}$ & 11.666 & & & & \\
\hline & Sig. & 0.195 & & & & \\
\hline
\end{tabular}

Sumber: Data diolah, 2019

Hasil uji pada Tabel 2 memberikan hasil dimana diperoleh besarnya adjusted $R 2$ (koefisien determinasi yang telah disesuaikan) adalah sebesar 0,492 . Ini berarti sebesar $49,2 \%$ variasi defisiensi audit secara signifikan dapat dipengaruhi oleh variabel workload $\left(\mathrm{X}_{1}\right)$, masa perikatan audit $\left(\mathrm{X}_{2}\right)$, dan spesialisasi auditor $\left(\mathrm{X}_{3}\right)$, sedangkan sisanya sebesar 50,8\% dijelaskan oleh faktor-faktor lain.

Hasil uji $\mathrm{F}$ (F test) menunjukkan bahwa nilai $\mathrm{F}$ hitung sebesar 11,666 dengan nilai signifikansi $\mathrm{P}$ value 0,000 yang lebih kecil dari $\alpha=0,05$, ini berarti model yang digunakan dalam penelitian ini telah memenuhi kriteria. Hasil ini berarti bahwa seluruh variabel independen mampu memprediksi atau menjelaskan fenomena Defisiensi audit. Hal ini berarti secara simultan Workload $\left(\mathrm{X}_{1}\right)$, Masa perikatan audit $\left(\mathrm{X}_{2}\right)$, dan Spesialisasi $\left(\mathrm{X}_{3}\right)$ berpengaruh signifikan terhadap Defisiensi audit pada 34 KAP yang diteliti.

Berdasarkan output regresi pada Tabel 2 diketahui bahwa nilai signifikansi variabel workload adalah sebesar 0,001 , nilai ini lebih kecil dari $\alpha=0,05$ yang berarti variabel workload berpengaruh signifikan pada defisiensi audit. Nilai koefisien variabel workload sebesar 0,035 yang menunjukkan bahwa workload berpengaruh pada defisiensi audit dengan arah hubungan positif.Hasil pada penelitian ini sesuai dengan hasil penelitian Rusli \& Wiratmaja (2016)yang meneliti pengaruh workload terhadap kualitas audit yang temuan penelitiannya menunjukkan bahwa workload telah secara signifikan menurunkan kualitas audit. Dalam penelitian Rusli \& Wiratmaja(2016)menemukan bahwa workload berpengaruh negatif pada kualitas audit. Hal tersebut berarti semakin tingginya workload seorang auditor akan menyebabkan meningkatkan terjadinya defisiensi audit.Proses audit ketika terjadinya workload akan menyebabkan kualitas audit menjadi lebih rendah dibandingkan saat tidak adanya tekanan workload karena dikhawatirkan tingginya workload dapat menimbulkan kelelahan bagi auditor dan menyebabkan auditor mengurangkan beberapa prosedur audit dari yang seharusnya dilakukan, selain itu tingginya workload juga mampu menurunkan kemampuan auditor dalam menemukan kekeliruan atau salah saji material dan penyimpangan yang terdapat dalam laporan keuangan.

Berdasarkan output regresi pada Tabel 2 menunjukkan bahwa nilai signifikansi variabel masa perikatan audit sebesar 0,046 , nilai ini lebih kecil dari $\alpha=0,05$ yang berarti variabel masa perikatan audit berpengaruh signifikan pada defisiensi audit. Nilai koefisien masa perikatan audit sebesar 0,430 menunjukkan bahwa variabel masa perikatan audit berpengaruh pada defisiensi audit dengan arah hubungan positif.Hasil pada penelitian ini sesuai dengan hasil penelitian Kurniasih \& Rohman(2014) yang menyatakan bahwa audit tenure atau masa perikatan audit berpengaruh negatif pada kualitas audit. Hal tersebut dapat diartikan bahwa semakin lama perikatan audit yang terjalin antara auditor dengan klien akan meningkatkan terjadinya defisiensi audit. Masa perikatan audit yang terlalu panjang juga dapat menimbulkan keakraban yang berlebihan sehingga dapat menciptakan terjadinya 

yang digunakan oleh Perusahaan Manufaktur yang Terdaftar di BEI Tahun 2015-2018

kolusi antara auditor dan klien.

Berdasarkan output regresi pada Tabel 2 bahwa nilai signifikansi variabel spesialisasi auditor sebesar 0,014, nilai ini lebih kecil dari $\alpha=0,05$ yang berarti variabel masa spesialisasi auditor berpengaruh signifikan pada defisiensi audit. Nilai koefisien spesialiasi auditor sebesar $-1,245$ menunjukkan bahwa variabel spesialisasi auditor berpengaruh pada defisiensi audit dengan arah hubungan negatif.Hasil pada penelitian ini sesuai dengan hasil penelitian (Ishak et al., 2015) yang menyebutkan bahwa spesialisasi auditor dapat berpengaruh positif terhadap kualitas audit. Sehingga, dapat disimpulkan bahwa spesialisasi auditor berpengaruh negatif terhadap terjadinya defisiensi audit, karena semakin tinggi pengetahuan auditor terhadap suatu bidang usaha akan memungkinkan auditor untuk menemukan kesalahan dan mendeteksi kecurangan yang dilakukan manajemen.

\section{SIMPULAN}

Berdasarkan hasil penelitian dan pembahasan, disimpulkan bahwa workload dan masa perikatan audit berpengaruh positif dan signifikan terhadap defisiensi audit sedangkan spesialisasi auditor berpengaruh negatif dan signifikan. Hal tersebut terjadi karena auditor semakin mengenal dan menguasai bisnis klien karena spesialisasi yang dimiliki dan memudahkan auditor untuk menemukan kesalahan dan mendeteksi adanya kecurangan.

Penelitian ini diharapkan mampu memberikan masukan bagi kantor akuntan publik untuk perlu mempertimbangankan beban kerja auditor untuk menghasilkan kualitas audit yang baik sehingga dapat mengindarkan terjadinya defisiensi audit.

Penelitian ini terdapat 50,8\% variasi dalam defisiensi audit yang dipengaruhi oleh variabelvariabel selain yang digunakan dalam model penelitian ini. Maka dari itu kepada peneliti selanjutnya disarankan untuk meneliti pengaruh variabel-variabel lain seperti skeptisme professional, rotasi audit, ukuran KAP, dan reputasi KAP.

\section{DAFTAR PUSTAKA}

Aobdia, D., \& Petacchi, R. (2018). Consequences of Low-Quality Audits for Engagement Partners. SSRN Electronic Journal. https://doi.org/10.2139/ssrn.2983900

Arens, A. A., Elder, R. J., \& Beasley, M. S. (2003). Auditing and Assurance Services, 14th Edition (Ninth Edit). Printice Hall.

Balsam, S., Krishnan, J., \& Yang, J. S. (2003). Auditor Industry Specialization and Earnings Quality. Auditing: A Journal of Practice and Theory, 22, 71-97. https://doi.org/10.2308/aud.2003.22.2.71

Chang, C. J., Luo, Y., \& Zhou, L. (2017). Audit deficiency and auditor workload: Evidence from PCAOB triennially inspected firms. Review of Accounting and Finance, 16(4), 478-496. https:// doi.org/10.1108/RAF-03-2017-0050

Febriyanti, N. M. D., \& Mertha, I. M. (2014). Pengaruh Masa Perikatan Audit, Rotasi KAP, Ukuran Perusahaan Klien, Dan Ukuran KAP Pada Kualitas Audit. E-Jurnal Akuntansi Universitas Udayana, 7(2), 503-518. Retrieved from https://ojs.unud.ac.id/index.php/Akuntansi/article/view/8946

Hansen, S. C., Kumar, K. R., \& Sullivan, M. W. (2007). Auditor Capacity Stress and Audit Quality: MarketBased Evidence from Andersen's Indictment. SSRN Electronic Journal. https://doi.org/10.2139/ ssrn. 1324830

Ishak, F. A. P., Perdana, H. D., \& Widjajanta, A. (2015). Pengaruh Rotasi Audit, Workload dan Spesialisasi Terhadap Kualitas Audit Pada Perusahaan Manufaktur Yang Terdaftar di Bursa Efek Indonesia Pada Tahun 2009 - 2013. Jurnal Organisasi Dan Manajemen, 11, 183-194. Retrieved from http:// jurnal.ut.ac.id/index.php/jom/article/view/234

Johnson, E., Khurana, I. K., \& Reynolds, J. K. (2002). Audit-Firm Tenure and the Quality of Financial Reports. Contemporary Accounting Research, 19(4), 637-660. https://doi.org/https://doi.org/10.1506/LLTHJXQV-8CEW-8MXD 
Wacana Ekonomi (Jurnal Ekonomi Bisnis dan Akuntansi), 20 (1) 2021, 48

Pengaruh Workload, Masa Perikatan Audit dan Spesialisasi Auditor Terhadap Defisiensi Audit pada KAP yang digunakan oleh Perusahaan Manufaktur yang Terdaftar di BEI Tahun 2015-2018

Kementerian Keuangan. (2019). Menkeu Jatuhkan Sanksi A uditor Laporan Keuangan Garuda Indonesia. Siaran Pers Kementerian Keuangan. https:/www.kemenkeu.go.id/media/12723/sp_menkeu-jatuhkan-sanksi -auditor-laporan-keuangan-garuda-indonesia_280619.pdf

Keputusan Menteri Keuangan Republik Indonesia Nomor 359/KMK.06/2003, Pub. L. No. Nomor 359/ KMK.06/2003 (2003).

Komite Nasional Kebijakan Governance atau KNKG. (2006). Pedoman Umum Good Corporate Governance.

Kurniasih, M., \& Rohman, A. (2014). Pengaruh Fee Audit, Audit Tenure, Dan Rotasi Audit Terhadap Kualitas Audit. Diponegoro Journal of Accounting, 3, 1-10. Retrieved from https:/ejournal3.undip.ac.id/ index.php/accounting/article/view/6199

López, D. M., \& Peters, G. F. (2012). The Effect of Workload Compression on Audit Quality. Auditing: A Journal of Practice \& Theory, 31(4), 139-165. https://doi.org/https://doi.org/10.2308/ajpt-10305

Nuratama, I. P. (2011). Pengaruh Tenur Dan Reputasi Kantor Akuntan Publik Pada Kualitas Audit Dengan Komite Audit Sebagai Variabel Moderasi (Studi Kasus Pada Perusahaan Manufaktur Yang Terdaftar Di BEI Tahun 2004-2009). Universitas Udayana.

Peraturan Menteri Keuangan Republik Indonesia PMK/17.01/2018, Pub. L. No. 17/PML.01/2008 (2008).

Peraturan Menteri Keuangan Nomor 206/PMK.01/2014. (2014).

Praptitorini, M. D., \& Januarti, I. (2011). Analisis Pengaruh Kualitas Audit, Debt Default Dan Opinion Shopping Terhadap Penerimaan Opini Going Concern. Jurnal Akuntansi Dan Keuangan Indonesia, 8 (1), 78-93. https://doi.org/10.21002/jaki.2011.05

Robbins, S. P. (2001). Perilaku Organisasi (Konsep, Kontroversi, Aplikasi) (Prenhallin).

Rusli, T. J., \& Wiratmaja, I. D. N. (2016). Komite Audit Sebagai Pemoderasi Pengaruh Workload Dan Masa Perikatan Audit Pada Kualitas Audit. Jurnal Ilmiah Akuntansi Dan Bisnis, 11, 47-53. https:// doi.org/10.24843/JIAB.2016.v11.i01.p06

Salno, H. M., \& Baridwan, Z. (2000). Analisis Perataan Penghasilan (Income Smoothing): Faktor-Faktor yang Mempengaruhi dan Kaitannya dengan Kinerja Saham Perusahaan Publik di Indonesia. The Indonesian Journal of Accounting Research (IJAR), 3(1), 17-34. https://doi.org/http:// doi.org/10.33312/ijar.35

Sari, C. M. A., \& Rustiana. (2016). Pemetaan Penerapan Standar Audit Berbasis ISA Pada Kantor Akuntan Publik (KAP) di Daerah Istimewa Yogyakarta. 28, 19-33. https://doi.org/10.24002/modus.v28i1.663

Setiawan W., L., \& Fitriany. (2011). Pengaruh Workload Dan Spesialisasi Auditor Terhadap Kualitas Audit Dengan Kualitas Komite Audit Sebagai Variabel Pemoderasi. Jurnal Akuntansi Dan Keuangan Indonesia, 8(1), 36-53. https://doi.org/10.21002/jaki.2011.03

Siregar, B. U. (2016). Pengaruh Audit Tenure, Reputasi Auditor, Spesialisasi Audit, dan Ukuran Perusahaan terhadap Kualitas Audit pada Perusahaan Property danReal Estate yang Terdaftar di Bursa Efek Indonesia. https://doi.org/10.1017/CBO9781107415324.004

Tuannakota, T. M. (2013). A udit Berbasis ISA (International Standards on Auditing). Salemba Empat.

Yoga, B. S., \& Dinarjito, A. (2019). Pengaruh Beban Kerja, Klien Baru, Dan Ukuran Klien Terhadap Defisiensi Audit. Jurnal Ilmiah Akuntansi Dan Bisnis, 14(1), 95-105. https://doi.org/10.24843/ JIAB.2019.v14.i01.p09 